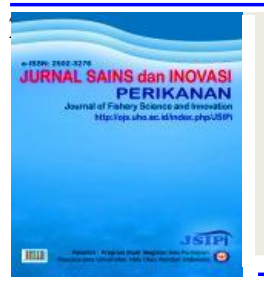

JURNAL SAINS dan INOVASI PERIKANAN

Journal of Fishery Science and Innovation

e-ISSN: 2502-3276

Vol. 1, No.2, 26-34, Juli 2017

http://ojs.uho.ac.id/index.php/JSIPi

\title{
Substitusi Tepung Kedelai (Glycine max) dengan Tepung Bungkil Biji Kapuk (Ceiba petandra) Hasil Fermentasi dalam Pakan Buatan terhadap Pertumbuhan dan Kelangsungan hidup Juvenil Udang Vaname (Litopenaeus vannamei).
}

\section{Substitution Soybean Meal (Glycine max) with Bungkil Kapok Seed Meal (Ceiba petandra) Fermented In Artificial Diet Toward Growth and Survival Rate of Juvenile Shrimp (Litopenaeus vannamei)}

\author{
Ni Gusti Ketut Triastini ${ }^{1{ }^{* *}}$ Wellem H. Muskita $^{2)}$, Prima Endang Susilowati ${ }^{3)}$ \\ ${ }^{1)}$ Program Studi Ilmu Perikanan Pascasarjana Universitas Halu Oleo, Kendari, Indonesia \\ ${ }^{2)}$ Fakultas Perikanan dan Ilmu Kelautan Universitas Halu Oleo, Kendari, Indonesia \\ ${ }^{3)}$ Fakultas MIPA Univ. Halu Oleo Kendari, Indonesia \\ Corresponing author $^{*}$ : gustitriastini12@gmail.com
}

\begin{abstract}
Kapok seed meal is a source of alternatif for plant protein that can be utilized to substitute soybean meal.The problem is kapok seed meal contains anti-nutrition, which are gossypol and cyclopropane fatty acid. One of the way to reducing these anti-nutrition can be used with biological is fermentation. This research to determine the effect of soybean meal substitution with bungkil kapok seed meal fermented in artificial diet toward growth and survival rate of juvenile vaname shrimp. The size of juvenil shrimp that were used in this research was $2.54 \pm 0.16 \mathrm{~g}$. Juvenil shrimp were kept for 40 days in an aquarium measuring $60 \times 50 \times 40 \mathrm{~cm}^{3}$ with a density of 15 each aquarium using a system of closed recirculation. Juvenil white shrimp were feed in a satiation manner in a frequency of 4 times a day. This study used 4 treatments and 3 replications. The treatments used consisted of treatment A (30\% soybean meal $+10 \%$ bungkil kapok seed meal fermented), treatment B (20\% soybean meal $+20 \%$ bungkil kapok seed meal fermented), treatment $\mathrm{C}(10 \%$ soybean meal $+30 \%$ bungkil kapok seed meal fermented), and treatment $\mathrm{D}$ (Commercial Feed X). Absolute growt (AG), specific growth rate (SGR),survival rate (SR), Feed efficiency (FE), feed consumption (FC), protein retention (PR) and energy retention (ER). A statistical test was performed on all parameters under evaluation. Result of study showed that treatment A, as compared to treatment B and C, yielded the best AG $(1,64 \mathrm{~g})$, SGR $(1,22 \%)$, SR $(84,44 \%)$, FE $(44,11 \%)$, FC $(25,68 \mathrm{~g}), \mathrm{PR}(1,02 \%)$ and ER $(19,54 \%)$. It can be concluded from the results of this study the substitution of $30 \%$ soybean meal with $10 \%$ bungkil kapok seed meal fermented in artificial diet affects the growth of juvenile shrimp.
\end{abstract}

Keywords: Bungkil Kapok seed, fermentation, cyclopropane fatty acid, shrimp vaname.

\begin{abstract}
ABSTRAK
Tepung bungkil biji kapuk merupakan sumber protein nabati alternatif yang dapat dimanfaakan untuk substitusi tepung kedelai. Masalahnya adalah bungkil biji kapuk mengandung antinutrisi yaitu gosypol dan asam lemak siklopropenat. Salah satu cara untuk mengurangi kedua antinutrisi tersebut dapat digunakan dengan cara biologi yaitu fermentasi. Penelitian ini bertujuan untuk mengetahui pengaruh substitusi tepung kedelai (TK) dengan tepung bungkil biji kapuk hasil fermentasi (TBBKHF) dalam pakan buatan
\end{abstract}


terhadap pertumbuhan dan kelangsungan hidup juvenil udang vaname. Udang vaname yang digunakan

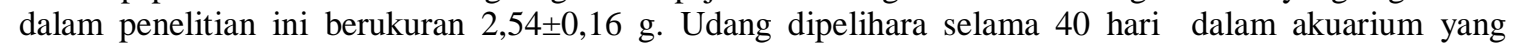
berukuran 60x50x40 cm dengan kepadatan 15 ekor/akuarium menggunakan sistem resirkulasi tertutup. Udang diberi pakan secara satiation dengan frekuensi 4 kali sehari. Penelitian ini menggunakan 4 perlakuan pakan uji dan diulang 3 kali. Perlakuan A (30\% TK + 10\% TBBKHF), perlakuan B (20\% TK + $20 \%$ TBBKHF), perlakuan C (10\% TK + 30TBBKHF), dan perlakuan D (Pakan Komersial X). Pertumbuhan mutlak (PM), laju pertumbuhan spesifik (LPS), kelangsungan hidup (SR), Konsumsi pakan $(\mathrm{KP})$, efisiensi pakan (EP), retensi protein (RP), dan retensi energi (RE) dievaluasi dalam penelitian ini. Uji statistik dilakukan pada semua parameter yang dievaluasi. Hasil penelitian menunjukkan bahwa perlakuan A bila dibandingkan dengan perlakuan B dan C memberikan PM (1,64 g), LPS (1,22\%), SR $(84,44 \%)$, KP $(25,68 \mathrm{~g})$, EP $(44,11 \%)$, RP $(1,02 \%)$ dan RE $(19,54)$ terbaik. Hasil penelitian dapat disimpulkan bahwa pemberian substitusi 10\% TBBKHP dengan 30\% TK dapat mempengaruhi pertumbuhan dan kelangsungan hidup juvenil udang vaname.

Kata kunci: Bungkil biji kapuk, fermentasi, asam lemak siklopropenat, udang vaname.

DOI: http://dx.doi.org/10.33772/jspi.

\section{PENDAHULUAN}

Udang vaname (Litopenaeus vannamei) merupakan salah satu komoditas perikanan yang mempunyai nilai ekonomis penting karena memiliki peluang sebagai usaha budidaya yang tidak berbeda jauh dengan peluang usaha perikanan lainnya. Dalam usaha budidaya udang vaname secara intensif, pakan buatan merupakan faktor yang sangat berperan penting untuk menentukan keberhasilan usaha tersebut. Hal ini disebabkan harga pakan yang mahal sehingga menjadi masalah dalam usaha budidaya udang vaname. Suprayudi (2010) menyatakan bahwa sekitar 48 - $89 \%$ dari setiap biaya produksi digunakan untuk pakan buatan.

Harga pakan yang tinggi disebabkan oleh mahalnya harga bahan baku pakan yaitu tepung ikan dan bungkil kedelai, karena kedua sumber protein tersebut masih impor, maka perlu alternatif bahan baku lokal yang harganya lebih kompetitif dari bahan impor, jumlahnya melimpah dan terjaga kontinuitasnya, sehingga diharapkan dapat mengurangi atau bahkan menggantikan penggunaan bahan baku pakan impor tersebut (Suprayudi, 2010). Salah satu peluang yang dapat dilakukan untuk mengatasi tingginya biaya pakan adalah dengan memanfaatkan bahan baku alternatif sebagai sumber protein yang mempunyai kandungan gizi yang cukup tinggi yaitu tepung bungkil biji kapuk (Ceiba petandra).

Tepung bungkil biji kapuk merupakan salah satu sumber protein nabati yang dapat digunakan sebagai sumber protein pakan udang. Beberapa penelitian tentang penggunaan tepung bungkil biji kapuk pada pakan udang vaname. Muskita (2011, 2012), menyimpulkan bahwa pemberian pakan yang mengandung tepung biji kapuk dapat mengakibatkan penurunan aktivitas enzim protease, lipase dan amilase serta terjadi kerusakan pada hepatopankreas udang vaname. Terjadinya penurunan aktivitas enzim protease, lipase dan amilase pada juvenil udang vaname disebabkan oleh bahan toksik yaitu gosipol dan asam lemak siklopropenat yang terdapat dalam pakan melebihi kadar yang mematikan pada juvenil udang vaname. Supaya tepung bungkil biji kapuk dapat dimanfaatkan sebagai sumber protein nabati bagi pakan udang vaname maka dapat dilakukan dengan mengurangi kandungan gosipol dan asam lemak siklopropenat.Salah satu metode penghilangan gosipol yang relatif aman adalah penggunaan mikroorganisme (biologis). Dalam proses fermentasi biji kapuk, mikroorganisme yang dipilih adalah mikroba yang mampu memetabolisme senyawa berbahaya dalam biji kapuk menjadi senyawa yang tidak berbahaya atau memanfaatkannya menjadi sumber energi bagi mikroba.

Hasil penelitian dilakukan untuk menghilangkan senyawa racun dan antinutrisi yang terkandung dalam bungkil biji kapuk melalui proses fermentasi bungkil biji kapuk yang difermentasi dengan cairan rumen domba sebanyak $30 \%$ dapat digunakan sebagai pengganti tepung bungkil kedelai dalam pakan ikan bawal Collosoma macropomum (Bani, 2013). Hal ini sejalan dengan data hasil fermentasi bungkil biji 
Ni Gusti K. Triastini et al.

JURNAL SAINS dan INOVASI PERIKANAN / Journal of Fishery Science and Innovation

Vol. 1, No. 2, 26-34, Juli 2017

kapuk menggunakan Aspergillus niger dapat meningkatkan kandungan protein kasar dari 28,35\% menjadi 38,08\% (Akmal et al. (2008).

Berdasarkan hal tersebut di atas, maka dilakukan penelitian untuk mengetahui pengaruh penggunaan tepung bungkil biji kapuk hasil fermentasi secara biologis (melibatkan mikroba) sebagai pengganti tepung kedelai dalam pakan buatan juvenil udang vaname.

\section{METODE PENELITIAN}

\section{Waktu dan Tempat}

Penelitian eksperimen ini dilaksanakan skala laboratorium di Laboratorium produksi Fakultas Perikanan dan Ilmu Kelautan (FPIK) Universitas Halu Oleo Kendari. Penelitian ini terdiri atas 2 tahap yaitu : Penelitian tahap I : Fermentasi bungkil biji kapuk Bahan yang digunakan dalam penelitian tahap 1 adalah bungkil biji kapuk diperoleh dari Kecamatan Pandaan Kabupaten Pasuruan Jawa Timur. Sumber mikroba yang digunakan untuk fermentasi bungkil biji kapuk adalah ragi tape. Hasil fermentasi dianalisa kandungan gosipol, asam lemak siklopropenat dan prokximat. Hasil kandungan gosipol dan asam lemak siklopropenat bungkil biji kapuk selanjutnya digunakan sebagai bahan baku pakan uji (penelitian tahap II).

Penelitian tahap II : Substitusi tepung kedelai dan tepung bungkil biji kapuk hasil fermentasi pada juvenil udang vaname

Pakan uji yang digunakan dalam penelitian ini disajikan pada Tabel 1. Pakan uji yang digunakan dengan menggunakan protein target $45 \%$.

Udang uji yang digunakan adalah juvenil udang vaname ukuran berat 2,54 $\pm 0,16 \mathrm{~g}$ yang diperoleh dari Kabupaten Kolaka Sulawesi Tenggara. Sebelum dilakukan perlakuan hewan uji diadaptasikan di dalam akuarium dan diberi pakan komersil selama 3 hari sebagai proses aklimatisasi hewan uji terhadap kondisi lingkungan percobaan.

Wadah yang digunakan adalah akuarium berukuran $60 \times 50 \times 40 \mathrm{~cm}$ berjumlah 12 buah. Keseluruhan akuarium dirangkai membentuk suatu sistem sirkulasi tertutup dengan menggunakan bak fiber. Sebelum dilakukan penelitan terlebih dahulu aquarium diisi $80 \%$ dari volume akuarium dengan air laut berasal dari BBU Mata yang telah disterilkan. Sistem sirkulasi ini diberikan aerasi pada setiap akuarium.
Sebelum dilakukan pemeliharaan, juvenil udang uji dipuasakan selama 24 jam. Sebanyak 180 ekor juvenil udang uji yang mempunyai ukuran berat ratarata 2,54 $\pm 0,16 \mathrm{~g}$ dimasukkan kedalam 12 buah aquarium masing-masing dengan kepadatan 15 ekor per aquarium. Pemberian pakan dilakukan 4 kali sehari yaitu pukul 06.00, 10.00, 14.00 dan 22.00.

Pemberian pakan dilakukan berdasarkan biomassa udang (3-5\%/hari) dan sisa pakan diambil dari dasar wadah pada keesokan harinya selanjutnya dikeringkan dan ditimbang sebagai dasar dalam perhitungan efisiensi pakan.

Tabel 1. Komposisi pakan uji

\begin{tabular}{lcccc}
\hline \multirow{2}{*}{\multicolumn{1}{c}{ Bahan Baku }} & \multicolumn{5}{c}{ Komposisi pakan uji pada setiap } \\
& \multicolumn{5}{c}{ perlakuan (\%) } \\
\cline { 2 - 5 } & 24 & B & C & D*** \\
\hline Tepung ikan & 24 & 24 & 24 & - \\
Tepung kepala udang & $\mathbf{3 0}$ & $\mathbf{2 0}$ & $\mathbf{1 0}$ & - \\
Tepung kedelai & $\mathbf{1 0}$ & $\mathbf{2 0}$ & $\mathbf{3 0}$ & - \\
TBBKHF* & 1 & 1 & 1 & - \\
Tepung jagung & 5 & 5 & 5 & - \\
Tepung Dedak halus & 1 & 1 & 1 & - \\
Tepung Terigu & 1 & 1 & 1 & - \\
Tepung Tapioka & 1 & 1 & 1 & - \\
Tepung Sagu & 0,5 & 0,5 & 0,5 & - \\
Minyak ikan & 0,5 & 0,5 & 0,5 & - \\
Minyak Cumi & 2 & 2 & 2 & - \\
TOP Mix** & 100 & 100 & 100 & - \\
Total & & & & \\
\hline Keterangan: & &
\end{tabular}

Keterangan :

TBBKHF : Tepung Bungkil Biji Kapuk Hasil Fermentasi

TOP MIX**: A, D3, E, K, B1, B2, B6, B12, C, Ca-Dpantothenate, Niacin,Cholin,Chloride,Methionine,Lysine, Manganese, Iron, Lodine, Zine, Cobalt, Copper, Santoquin (Antioxidant), Zine bacitracein.

D*** : Pakan komersial X

Wadah penelitian dilengkapi shelter berupa kain strimin berukuran $25 \times 25 \mathrm{~cm}$ yang ditempatkan di sudut akuarium yang diberi pemberat batu kecil untuk menghindari kanibalisme. Kualitas air dijaga dengan menyipon setiap pagi hari untuk menghilangkan sisasisa pakan dan kotoran. Setiap 2 hari dilakukan penambahan air sebanyak $30 \%$ dari volume bak.

Pengamatan dan pengukuran kualitas air meliputi pengamatan suhu air dengan termometer sedangkan pengukuran salinitas dengan menggunakan refraktometer, pengukuran nilai $\mathrm{pH}$ menggunakan $\mathrm{pH}$ meter. Lama pemeliharaan juvenil udang vaname selama 40 hari, sampling dilakukan setiap 10 sekali yaitu pada pagi hari

\section{Rancangan percobaan}

Rancangan yang digunakan adalah rancangan acak lengkap (RAL) dengan 4 traf perlakuan dan 3 ulangan. Perlakuan yang digunakan dalam penelitian 
ini adalah perlakuan A $(30 \%$ TK $+10 \%$ TBBKHF),perlakuan B (20\% TK $+20 \%$ TBBKHF), perlakuan $\mathrm{C}(10 \% \mathrm{TK}+30 \%$ TBBKHF $)$, dan perlakuan D (Pakan Komersial X).

\section{Analisis Kimia}

Analisis meliputi analisis proksimat pakan (Takeuci, 1988), yang meliputi analisa protein dengan metode Kjehldahl, lemak dengan metode ekstraksi dengan alat Soxhlet, kadar air dengan metode pengeringan dalam oven dengan suhu $110^{\circ} \mathrm{C}$, kadar abu dengan metode pemanasan dalam tanur $600^{\circ} \mathrm{C}$, dan serat kasar dengan metode pelarutan sampel dengan asam dan basa kuat. Metode fermentasi menurut Kompiang et al. 1994, metode analisis kandungan gosipol bebas menurut Shazia., et al. (2010), metode analisa kandungan asam lemak siklopropenat menurut Zahirma (1986).

\section{Parameter Yang Diuji}

a. Pertumbuhan Mutlak (PM)

Pertumbuhan mutlak udang uji dihitung berdasarkan bobot tubuh digunakan rumus $\mathrm{Hu}$ et al. (2008).

Keterangan :

$$
\mathrm{PM}=\mathrm{W}_{\mathrm{t}}-\mathrm{W}_{0}
$$

PM : Pertumbuhan mutlak rata-rata $(\mathrm{g})$

$\mathrm{W}_{\mathrm{t}}$ : Bobot rata-rata udang pada waktu $\mathrm{t}(\mathrm{g})$

$\mathrm{W}_{0}$ : Bobot rata-rata udang pada awal penelitian $(\mathrm{g})$

\section{b. Laju Pertumbuhan Spesifik}

Laju Pertumbuhan Spesifik (LPS) diukur setiap selang waktu 10 hari sekali, selama 40 hari. Berdasarkan bobot tubuh menggunakan rumus $\mathrm{Hu}$ et al. (2008).

$$
\text { LPS } \quad=\frac{\operatorname{Ln~}_{\mathrm{t}}-\mathrm{Ln} \mathrm{W}_{0}}{\mathrm{t}} \times 100 \%
$$

Keterangan :

$$
\begin{aligned}
& \text { LPS = Laju Pertumbuhan Spesifik (\%) } \\
& \mathrm{W}_{\mathrm{t}}=\text { Bobot rata-rata udang pada waktu } \mathrm{t} \\
& \text { (g) } \\
& \mathrm{W}_{0}=\text { Bobot rata-rata udang pada awal } \\
& \text { penelitian }(\mathrm{g}) \\
& \mathbf{t}=\text { Periode waktu (hari) }
\end{aligned}
$$

c. Kelansungan Hidup

Tingkat kelangsungan hidup (SR) dihitung berdasarkan persamaan (Zonneveld et al. 1991).

$$
\mathrm{SR}=\frac{\mathrm{N}_{\mathrm{t}}}{\mathrm{N}_{0}} \times 100 \%
$$

Keterangan :

$\mathrm{SR}=$ Kelangsungan hidup udang $(\%)$
$\mathrm{N}_{\mathrm{t}}$ = Jumlah udang pada akhir penelitian (ekor)

$\mathrm{N}_{0}=$ Jumlah udang pada awal penelitian (ekor)

d. Efisiensi Pakan

Efisiensi pakan (EP) dihitung dengan menggunakan rumus Watanabe (1988).

$$
\mathrm{EP}(\%)=\frac{1}{\mathrm{FCR}} \times 100 \%
$$

Keterangan :

$$
\begin{aligned}
& \mathrm{EP}=\text { Efisiensi pakan }(\%) \\
& \mathrm{FCR}=\text { Rasio Konversi Pakan }
\end{aligned}
$$

\section{e. Konsumsi Pakan}

Bores et al, (2006) menyatakan bahwa jumlah pakan yang dikonsumsi per hari dihitung berdasarkan jumlah pakan yang dikonsumsi (g) dalam sehari dengan jumlah udang.

\section{f. Retensi Protein}

Nilai Retensi Protein dihitung menggunakan rumus yang dikemukan oleh Takeuchi (1988) dalam Watanabe (1988).

$$
\mathrm{RP}=\frac{F-I}{p} X 100 \%
$$

Keterangan :

$\mathrm{RP}=$ Retensi Protein $(\%)$

$\mathrm{F}=$ Bobot protein tubuh udang pada akhir pemeliharaan

I = Bobot protein tubuh udang pada awal pemeliharaan

$\mathrm{P}=$ Bobot protein yang dikonsumsi

g. Retensi Energi

Retensi Energi dihitung berdasarkan formula Jouncey dan Ross (1988).

$\mathrm{RE}=\frac{(\text { Energi dalam tubuh akhir }(\mathrm{g}))-(\text { Energi dalam tubuh udang }}{\text { Energi yang dikonsumsi }(\mathrm{g})} \times 100 \%$

\section{Analisis data}

Parameter yang diukur yaitu pertumbuhan mutlak (PM), laju pertumbuhan spesifik (LPS),kelangsungan hidup (SR), efisiensi pakan, konsumsi pakan, retensi protein, retensi energi dianalisis statistik (Supamattaya et al., 2005) dengan menggunakan komputer dengan program master SPSS ver 16.0 for Windows. 


\section{HASIL DAN PEMBAHASAN}

Hasil

Hasil yang diperoleh setelah pemeliharaan menunjukkan bahwa substitusi antara tepung kedelai dengan tepung bungkil biji kapuk hasil fermentasi dalam pakan memberikan pengaruh yang tidak berbeda nyata $(p>0,05)$ antar perlakuan terhadap pertumbuhan mutlak, laju pertumbuhan spesifik, konsumsi pakan, retensi protein dan retensi energi tetapi memberikan pengaruh yang berbeda nyata $(\mathrm{p}<0,05)$ antar perlakuan terhadap kelangsungan hidup dan efisiensi pakan.

Tabel 2. Nilai rata-rata Pertumbuhan Mutlak (PM), Laju Pertumbuhan Spesifik (LPS), Suevival Rate (SR), Efisiensi Pakan (EP), Konsumsi Pakan (KP), Retensi Protein(RP), Retensi energi (RE)

\begin{tabular}{|c|c|c|c|c|}
\hline $\mathrm{Pa}$ & \multicolumn{4}{|c|}{ Pakan } \\
\hline $\begin{array}{l}\text { me } \\
\text { ter }\end{array}$ & A & B & $\mathrm{C}$ & $\mathrm{D}$ \\
\hline PM & $1,64 \pm 0,72^{\mathrm{a}}$ & $1,25 \pm 0,09^{\mathrm{a}}$ & $1,07 \pm 0,35^{\mathrm{a}}$ & $1,64 \pm 0,32^{\mathrm{a}}$ \\
\hline $\begin{array}{l}\text { LP } \\
\text { S }\end{array}$ & $1,22 \pm 0,33^{\mathrm{a}}$ & $1,03 \pm 0,04^{\mathrm{a}}$ & $0,87 \pm 0,22^{\mathrm{a}}$ & $1,17 \pm 0,21^{\mathrm{a}}$ \\
\hline SR & $88,44 \pm 3,85^{\mathrm{c}}$ & $68,89 \pm 3,85^{\mathrm{ab}}$ & $57,78 \pm 7,70^{\mathrm{a}}$ & $80,00 \pm 6,67^{\text {bc }}$ \\
\hline EP & $28,21 \pm 3,52^{\mathrm{a}}$ & $27,35 \pm 2,30^{\mathrm{a}}$ & $\begin{array}{l}30,50 \pm \\
4,67^{\mathrm{a}}\end{array}$ & $44,11 \pm 3,38^{\mathrm{b}}$ \\
\hline KP & $25,68 \pm 4,09^{\mathrm{a}}$ & $23,44 \pm 2,09^{\mathrm{a}}$ & $22,05 \pm 2,21^{\mathrm{a}}$ & $19,24 \pm 1,47^{\mathrm{a}}$ \\
\hline RP & $1,02 \pm 0,23^{\mathrm{a}}$ & $1,00 \pm 0,08^{\mathrm{a}}$ & $0,87 \pm 0,11^{\mathrm{a}}$ & $0,91 \pm 0,05^{\mathrm{a}}$ \\
\hline RE & $19,54 \pm 4,17^{\mathrm{a}}$ & $18,06 \pm 1,37^{\mathrm{a}}$ & $17,71 \pm 2,05^{\mathrm{a}}$ & $18,91 \pm 0,90^{\mathrm{a}}$ \\
\hline
\end{tabular}

*Huruf yang berbeda pada baris yang sama menunjukkan pengaruh yang tidak berbeda nyata $(p>0,05)$. Nilai yang tertera merupakan nilai rata-rata \pm standar deviasi dari tiga ulangan.

**keterangan: Pakan A(30\% TK + 10\%TBBKHF); Pakan B(20\%TK + 20\% TBBKHF);Pakan C(10\% TK+ 30\% TBBKHF);Pakan D (Pakan Komersial X).

a. Pertumbuhan Mutlak (PM)

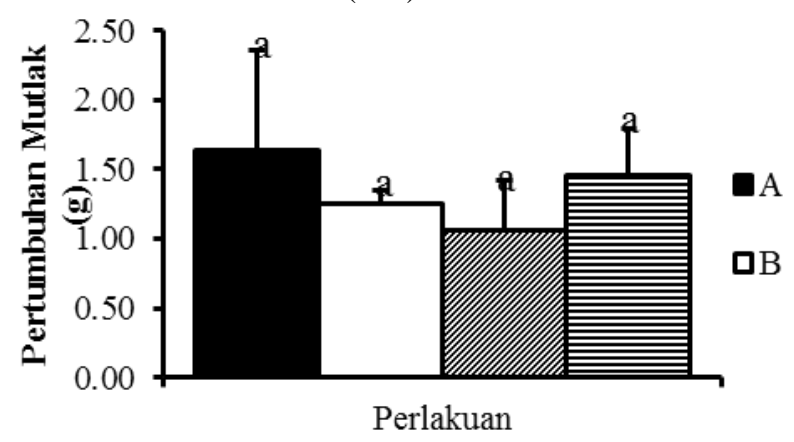

Gambar 1. Histogram pertumbuhan mutlak juvenil udangvaname. Pakan A(30\%TK + 10\% TBBKHF);
Pakan B (20\% TK + 20\% TBBKHF); Pakan C (10\% $\mathrm{TK}+30 \%$ TBBKHF); Pakan D (Pakan Komersial X).

Pertumbuhan mutlak tertinggi diperoleh pada pemberian pakan dengan perlakuan A $(30 \%$ TK + $10 \%$ TBBKHF) yaitu sebesar $1,64 \pm 0,72 \mathrm{~g}$, kemudian diikuti dengan perlakuan $\mathrm{D}$ (pakan komersial $\mathrm{X}$ ) yaitu sebesar $1,46 \pm 0,32 \mathrm{~g}$, perlakuan berikutnya adalah perlakuan B (20\% TK $+20 \%$ TTBKHF) yaitu $1,25 \pm 0,09 \mathrm{~g}$ dan terendah perlakuan $\mathrm{C}(10 \% \mathrm{TK}+$ $30 \%$ TBBKHF) yaitu sebesar $1,07+0,35 \mathrm{~g}$.

Hasil analisis ragam menunjukkan bahwa pakan uji yang diberikan tidak memberikan pengaruh nyata $(\mathrm{P}>0,05)$ antar perlakuan terhadap pertumbuhan mutlak juvenil udang vaname.

b. Laju pertumbuhan spesifik

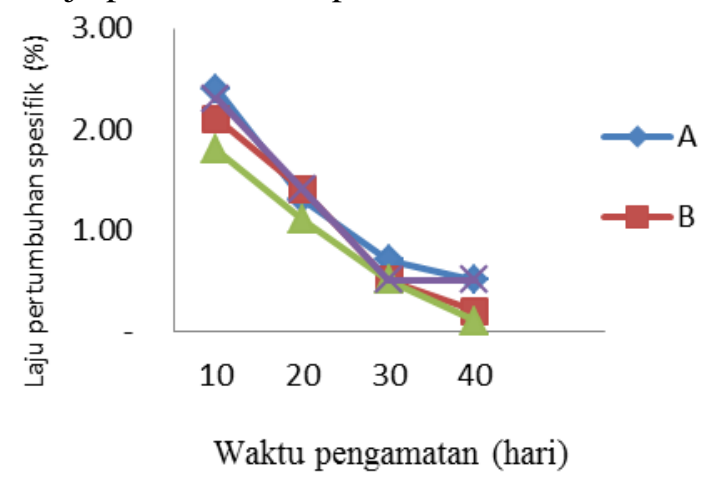

Gambar 2. Grafik laju pertumbuhan spesifik juvenil udang vaname. Pakan A (30\% TK $+10 \%$ TBBKHF); Pakan B (20\% TK + 20\% TBBKHF); Pakan C (10\% TK + 30\% TBBKHF); Pakan D (Pakan komersil X).

Rata-rata laju pertumbuhan spesifik pada 10 hari pengamatan tertinggi ditemukan pada perlakuan A $(30 \% \mathrm{TK}+10 \%$ TBBKHF $)$ sebesar $2,40 \%$, berikutnya pada perlakuan D (Pakan komersial X) yaitu $2,30 \%$, pada perlakuan B $(20 \% \mathrm{TK}+20 \%$ TBBKHF) yaitu $2,10 \%$, dan terendah pada perlakuan C $(10 \%$ TK $+30 \%$ TBBKHF $)$ yaitu $1,80 \%$. Pada pengamatan 20 hari laju pertumbuhan spesifik tertinggi ditemukan pada perlakuan B $(20 \% \mathrm{TK}+20 \%$ TBBKHF), perlakuan D (pakan komersial X) yaitu $1,40 \%$, perlakuan A $(30 \% \mathrm{TK}+10 \% \mathrm{TBBKHF})$ yaitu $1,30 \%$ dan terendah perlakuan $\mathrm{C}(10 \% \mathrm{TK}+$ $30 \%$ TBBKHF) yaitu $1,10 \%$. Pengamatan hari ke 30 sampai dengan hari ke 40 laju pertumbuhan spesifik tertinggi ditemukan pada perlakuan A $(30 \%$ TK + $10 \%$ TBBKHF), perlakuan D (pakan komersial X) yaitu sebesar $0,50 \%$, perlakuan B $(20 \% \mathrm{TK}+20 \%$ 
TBBKHF) yaitu $0,20 \%$ dan terendah pada perlakuan $\mathrm{C}(10 \% \mathrm{TK}+30 \% \mathrm{TBBKHF})$ yaitu $0,10 \%$.

Pengamatan mulai 10 hari pertama sampai hari ke 30 terjadi penurunan laju pertumbuhan spesifik yang sangat signifikan pada semua perlakuan, namun setelah hari ke 30 perlakuan A $(30 \%$ TK $+10 \%$ TBBKHF) dan perlakuan D (pakan komersial X) cenderung merata hingga hari ke 40. Sedangkan perlakuan B $(20 \% \mathrm{TK}+20 \% \mathrm{TBBKHF})$ dan perlakuan $\mathrm{C}(10 \% \mathrm{TK}+30 \% \mathrm{TBBKHF})$ cenderung menurun hingga hari ke 40.

Hasil analisis ragam menunjukkan bahwa pakan uji yang diberikan tidak memberikan pengaruh nyata $(\mathrm{P}>0,05)$ antar perlakuan terhadap laju pertumbuhan spesifik juvenil udang vaname.

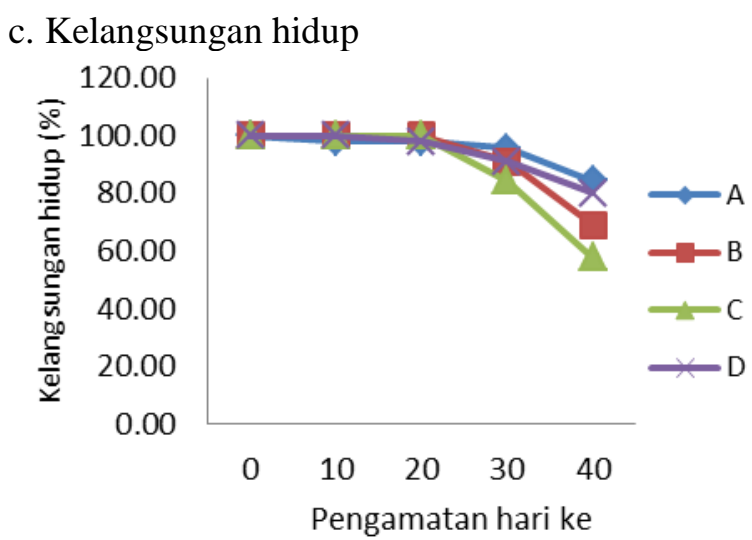

Gambar 3. Grafik tingkat kelangsungan hidup juvenil udang vaname dengan selang waktu 10 hari.Keterangan:Pakan A $(30 \%$ TK $+10 \%$ TBBKHF);Pakan B (20\% TK + 20\% TBBKHF); Pakan C (10\% TK + 30\% TBBKHF); Pakan D (Pakan komersil X).

Rata-rata kelangsungan hidup tertinggi ditemukan pada perlakuan A (30\% TK $+10 \%$ TBBKHF) yaitu sebesar $84,44 \%$, kemudian diikuti dengan perlakuan D (pakan komersial X) yaitu sebesar 80,00\%, perlakuan B (20\% TK $+20 \%$ TBBKHF) yaitu $68,89 \%$, dan terendah perlakuan $\mathrm{C}(10 \% \mathrm{TK}+30 \%$ TBBKHF) yaitu sebesar $57,78 \%$.

Hasil analisis ragam menunjukkan bahwa pakan uji memberikan pengaruh berbeda nyata $(\mathrm{P}<0,05)$ antar perlakuan terhadap kelangsungan hidup juvenil udang vaname. Perlakuan A $(30 \%$ TK $+10 \%$ TBBKHF) berbeda nyata dengan perlakuan B $(20 \%$ $\mathrm{TK}+20 \%$ TBBKHF) dan perlakuan C $(10 \% \mathrm{TK}+$
$30 \%$ TBBKHF), tetapi tidak berbeda nyata dengan perlakuan D (pakan komersial X).

\section{d. Efisiensi pakan}

Rata-rata efisiensi pakan tertinggi terdapat pada perlakuan D (pakan komersial X) yaitu 44,11 $\pm 3,38$ kemudian diikuti pada perlakuan C $(10 \% \mathrm{TK}+30 \%$ TBBKHF) yaitu sebesar 30,50 \pm 4,67, kemudian perlakuan A (30\% TK + 10\% TBBKHF) yaitu sebesar $28,21 \pm 3,52$, dan terendah pada perlakuan B $(20 \%$ $\mathrm{TK}+20 \%$ TBBKHF) yaitu $27,35 \pm 2,30$.

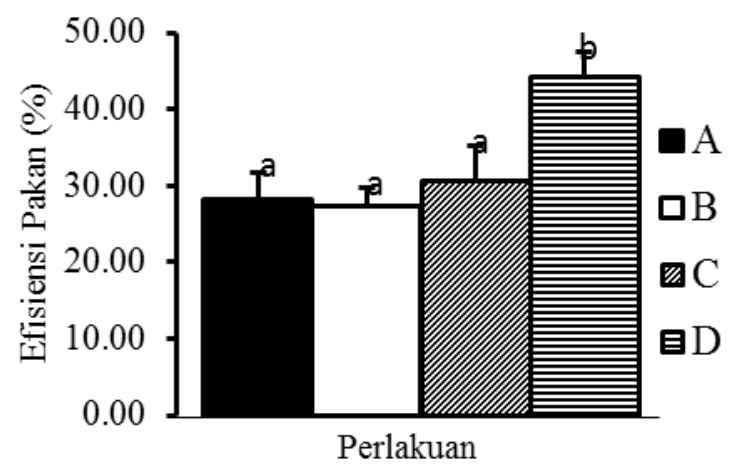

Gambar 4. Histogram efisiensi pakan juvenil udang vaname. Pakan A (30\% TK + 10\% TBBKHF); Pakan B $(20 \%$ TK + 20\% TBBKHF); Pakan C $(10 \%$ TK + $30 \%$ TBBKHF); Pakan D (pakan komersil X).

Hasil analisis ragam menunjukkan bahwa pakan uji memberikan pengaruh berbeda nyata $(\mathrm{P}<0,05)$ antar perlakuan terhadap efiiensi pakan juvenil udang vaname. Perlakuan A $(30 \% \mathrm{TK}+10 \% \mathrm{TBBKHF})$, perlakuan B $(20 \% \mathrm{TK}+20 \% \mathrm{TBBKHF})$ dan perlakuan C $(10 \% \mathrm{TK}+30 \%$ TBBKHF $)$ tidak berbeda nyata, tetapi berbeda nyata terhadap perlakuan D (pakan komersial X).

e. Konsumsi pakan

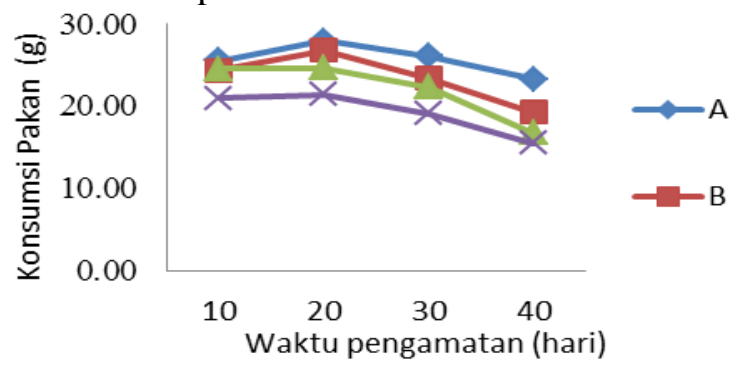

Gambar 5. Grafik konsumsi pakan juvenil udang vaname. Pakan A (30\% TK + 10\% TBBKHF); Pakan B $(20 \%$ TK + 20\% TBBKHF); Pakan C (10\% TK + 30\% TBBKHF); Pakan D (pakan komersil X). 
Rata-rata konsumsi $10 \%$ TBBKHF) yaitu $25,68 \mathrm{~g}$; kemudian pada perlakuan B $(20 \% \mathrm{TK}+20$ $\%$ TBBKHF) yaitu $23,44 \mathrm{~g}$, berikutnya pada perlakuan C (10\% TK $+30 \%$ TBBKHF) yaitu $22,05 \mathrm{~g}$ dan terendah perlakuan D (pakan komersial X) yaitu 19,24 g. Hasil analisis ragam menunjukkan bahwa pakan uji tidak memberikan pengaruh nyata $(\mathrm{P}$ $>0,05)$ antar perlakuan terhadap konsumsi pakan juvenil udang vaname.

f. Retensi protein

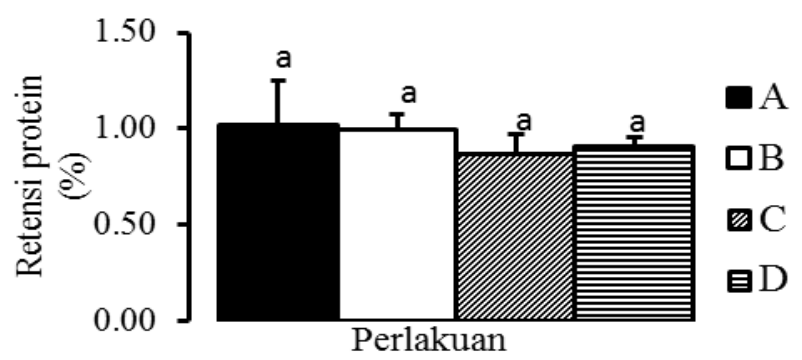

Gambar 6. Histogram retensi protein juvenil udang vaname. Pakan A (30\% TK + 10\% TBBKHF); pakan B (20\% TK+ $20 \%$ TBBKHF); pakan C (10\% TK + 30\% TBBKHF); pakan D (pakan komersil X).

Rata-rata retensi protein tertinggi pada perlakuan A (30\% TK + 10\% TBBKHF) yaitu $1,02 \pm 0,23 \%$, kemudian diikuti perlakuan B $(20 \%$ TK $+20 \%$ TBBKHF) yaitu $1,00 \pm 0,08 \%$, perlakuan D ( pakan komersial X) yaitu $0,91 \pm 0,05 \%$ dan terendah pada perlakuan $\mathrm{C}(10 \% \mathrm{TK}+30 \% \mathrm{TBBKHF})$ yaitu $0,87 \pm 0,11 \%$.

Hasil analisis ragam menunjukkan bahwa pakan uji tidak memberikan pengaruh nyata $(\mathrm{P}>$ $0,05)$ antar perlakuan terhadap retensi protein juvenil udang vaname.

g. Retensi energi

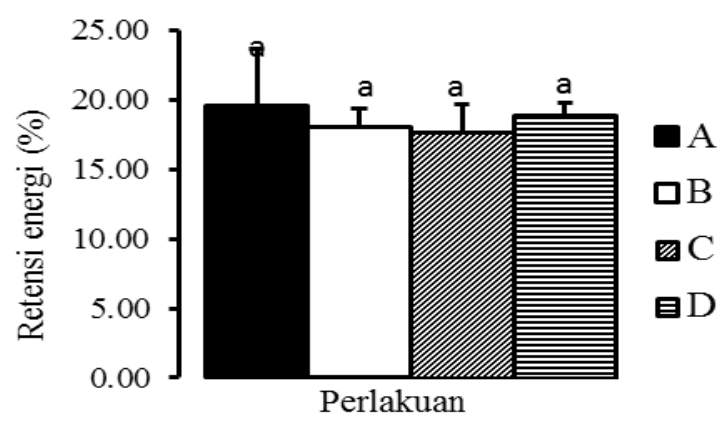

Gambar 7. Histogram retensi energi juvenil udang vaname. Pakan A (30\% TK + 10\% TBBKHF); Pakan
B $(20 \%$ TK + 20\% TBBKHF); Pakan C $(10 \%$ TK + 30\% TBBKHF); Pakan D (pakan komersil X).

Retensi energi tertinggi pada perlakuan A (30\% $\mathrm{TK}+10 \%$ TBBKHF) sebesar 19,54 $\pm 4,17 \%$, kemudian diikuti perlakuan $\mathrm{D}$ (pakan komersial X) sebesar 18,91 $\pm 0,90 \%$, perlakuan B $(20 \% \mathrm{TK}+20 \%$ TBBKHF) sebesar $18,06 \pm 1,37 \%$, dan terendah perlakuan $\mathrm{C}(10 \% \mathrm{TK}+30 \% \mathrm{TBBKHF})$ sebesar $17,71 \pm 2,05 \%$. Hasil analisis ragam menunjukkan bahwa pakan uji tidak memberikan pengaruh nyata $(\mathrm{P}$ $>0,05)$ antar perlakuan terhadap retensi energi juvenil udang vaname.

\section{Pembahasan}

Hasil penelitian menunjukkan bahwa pemberian diatas $10 \%$ TBBKHF dalam pakan buatan mempengaruhi pertumbuhan mutlak, laju pertumbuhan spesifik, kelangsungan hidup, efisiensi pakan, konsumsi pakan, retensi protein dan retensi energi.

Pada perlakuan dengan pemberian $10 \%$ TBBKHF dalam pakan memberikan rata - rata pertumbuhan mutlak tertinggi yaitu 1,64 g (Gambar 1). Hal ini disebabkan oleh pemanfaatan pakan yang lebih baik sehingga memberikan pertumbuhan terbaik. Menurut Effendie. (1979) menyatakan bahwa pertumbuhan udang dipengaruhi oleh keturunan, jenis kelamin, umur, kepadatan, parasit dan penyakit serta kemampuan memanfaatkan makanan. Selain memberikan pertumbuhan mutlak terbaik, hal ini juga memberikan hasil laju pertumbuhan spesifik terbaik yaitu $1,22 \%$ (Gambar 2) bila dibandingkan dengan perlakuan B (20\% TK + 20\% TBBKHF) dan perlakuan C (10\% TK + 30\% TBBKHF). Berdasarkan data menunjukkan nilai rata-rata laju pertumbuhan spesifik lebih tinggi pada masa awal pemeliharaan dan mengalami penurunan seiring dengan bertambahnya masa pemeliharaan udang. Menurut Budiardi, (2007) bahwa laju pertumbuhan spesifik menunjukkan penurunan dengan meningkatnya bobot rata-rata seiring dengan meningkatnya masa pemeliharaan.

Perlakuan A $(30 \%$ TK $+10 \%$ TBBKHF $)$ selain memberikan pertumbuhan mutlak terbaik, laju pertumbuhan spesifik terbaik, hal ini didukung pula tingkat kelangsungan hidup, konsumsi pakan yang tinggi, serta retensi protein dan retensi energi. Pertambahan bobot badan sangat dipengaruhi oleh konsumsi pakan, karena konsumsi pakan menentukan masuknya zat nutrisi ke dalam tubuh yang selanjutnya 
dipakai untuk pertumbuhan. Wyban dan Sweeny. (1991) mengemukan bahwa pemberian pakan yang tepat baik kualitas maupun kuantitas dapat memberikan pertumbuhan optimum bagi udang.

Peningkatan pemberian TBBKHF diatas 10\% memberikan hasil pertumbuhan mutlak, laju pertumbuahan spesifik, kelangsungan hidup, konsumsi pakan, retensi protein dan retensi energi yang terendah. Hal ini diduga oleh peningkatan jumlah bahan toksik dan asam lemak siklopropenat yang telah terakumulasi dalam hepatopankreas,sehingga menyebabkan kerusakan pada hepatopankreas.

Francis et al. (2001) dalam Muskita (2012) menyatakan bahwa gejala yang diakibatkan adanya gosipol dalam pakan udang yaitu pertumbuhan menurun, perubahaan nekrotik pada sel hati, serta adanya akumulasi pigmen granulaseroit di hati.Menurut Roehm et al. (1967) menyatakan bahwa ikan rainbow trout yang ditambahkan $1 \%$ gosipol dalam pakan menyebabkan pertumbuhan ikan menurun sekitar 50\% dibandingkan dengan kontrol. Pada saat tertentu peningkatan kandungan tepung bungkil biji kapuk hasil fermentasi dalam pakan mengakibatkan kelangsungan hidup juvenil udang vaname menurun.

\section{KESIMPULAN}

Dapat disimpulkan bahwa substitusi $30 \%$ tepung kedelai dengan $10 \%$ tepung bungkil biji kapuk hasil fermentasi dalam pakan buatan dapat mempengaruhi pertumbuhan dan kelangsungan hidup juvenil udang vaname (L. vannamei).

\section{DAFTAR PUSTAKA}

Bani C.S., 2013. Evaluasi tepung biji kapuk (Ceiba petandra Gaertn) yang difermentasi cairan rumen domba sebagai pengganti bungkil kedelai dalam pakan ikan bawal (Collosoma macropom). [Skripsi]. Bogor (ID): Institut Pertanian Bogor.

Bores G.E., R.C. Cerecedo, S.R. Meza, dan A.G. Yee., 2006. Partial replacement of red crab (pleuroncodes planipes) meal for fish meal in practical diets for thr white shrimp Litopenaeus vannamei. Effect on growth and in vivo digestibility. Aquaculture, 256, 414-422.
Effendie M.I., 1997. Metode Biologi Perikanan. Cetakan pertama. Penerbit Yayasan Dwi Sri Bogor, 112p.

Francis G., Harinder P.S.M., Becker., 2001. Antinutrisional factors present in plant-derived alternate fish feed ingredients and their effects in fish. Aquaculture. 199: 197-227

Hua Y., Tan, B., mai, K., Ai, Q., S.,Cheng, K., 2008. Growth and Body Composition of Juvenil White Shrimp, Litopenaeus vannamei, Fed Different Ratios of Dietary Protein to Energy. Jurnal Aquaculture Nutrition, 14 : 499-506.

Jouncey K., Ross B., 1988. A Guide to Tilapia Feeds and Feeding. Institute of Aquaculture of Stirling Scotland.

Kompiang I P., Darma T., Purwadaria A., Sinurat., Supriyati., 1994. Laporan Hasil Penelitian Protein Enrichment : Studi Cassava Enrichment melalui Proses Biologi untuk Ternak Monogastrik. Balitnak bekerjasama dengan Proyek Pengembangan Penelitian Pertanian Nasional Badan Litbang Pertanian.

Muskita W.H., 2011. Efek Pemberian Tepung bungkil biji Kapuk (Ceiba petandra): Hubungannya dengan aktivitas Enzim pencernaan juvenil Udang vaname (Litopenaeus vannamei). Ichthyos. Jurnal Penelitian Ilmu-Ilmu Perikanan dan kelautan. Vol. 10 nomor 2 Juli 2011.

Muskita WH. 2012. Substitusi tepung bungkil kedele, Glycine max, dengan tepung bungkil biji kapuk, Ceiba petandra, dalam pakan juvenil udang vaname Litopenaeus vannamei : Kajian histologi, enzimatik, dan komposisi asam lemak tubuh. [Disertasi]. Bogor (ID): Institut Pertanian Bogor.

Roehm J.N., Lee D.J., Sinnhuber R.O., 1967. Accumulation and elimination of dietary gossypol in the organ of rainbow trout. Lipids, 5(1) : 80-81

Shazia M., Muhammad A.S., Asia P., 2010. Pakistan Journal of Nutrition 9 (10): 994-997, 2010 .ISSN 1680-5194. (C) Asian Network for Scientific Information, 2010

Suprayudi M.A., 2010. Pengembangan penggunaan bahan baku lokal untuk pakan ikan/udang: status terkini dan prospeknya. Makalah disajikan pada Semi-Loka Nutrisi dan Teknologi Pakan Ikan/Udang, Bogor 26 Oktober 2010. Badan Litbang Kelautan dan Perikanan, KKP bekerjasama dengan ISPIKANI, Jakarta. 
34 Ni Gusti K. Triastini et al.

JURNAL SAINS dan INOVASI PERIKANAN / Journal of Fishery Science and Innovation

Vol. 1, No. 2, 26-34, Juli 2017

Watanabe, T. 1988., Fish nutrition and mariculture.

Department of aquatic bioscience. tokyo university of fisheries. JICA. $223 \mathrm{pp}$.

Wyban J.A., Sweeny J.N., 1991. Intensif Shrimp Production Technology. The Oceanic Institute. Honolulu. Hawaii USA, 158pp.

Zahirma U., 1986. Analisa asam siklopropenat dari bungkil biji kapuk dengan tehnik kromatografi gas. Skripsi. Fakultas MIPA. Universitas Indonesia. Jakarta.

Zonneveld N., Huisman E. A. Boon, J. H., 1991. Prinsip-prinsip budidaya ikan. PT. Gramedia Pustaka Utama. Jakarta. 318 p. 